\title{
Sustainability of Tourism Development in the city of Ain-Sukhna, Egypt
}

* Professor Dr. Yasser Mahgoub (D) p

Faculty of Architecture, Galala University, Egypt E-mail:ymahgoub@gu.edu.eg

\begin{tabular}{|l|}
\hline ARTICLE INFO: \\
\hline Article History: \\
Received 18 June 2021 \\
Accepted 5 August 2021 \\
Available online 14 August 2021 \\
\hline Keywords: \\
Coastal Tourism; \\
Sustainable Development; \\
Cultural Resource; \\
Ain-Sukhna; \\
Galala City. \\
\end{tabular}

This article is an open access
article distributed under the terms and
conditions of the Creative Commons
Attribution $(\mathrm{CC}$ BY $)$ license
This article is published with open
access at www.ijcua.com

\section{ABSTRACT}

Check for

Updates

Tourism is a major economic source for Egypt, due to its significant natural and cultural attractions. Yet, rapid development and construction of touristic facilities have a negative impact on the fragile natural and cultural heritage. This paper studies the recent touristic developments of the coastal stretch of Ain-Sukhna on the Red Sea coastal region of Galala Mountain, and their impact on the surrounding natural and cultural attractions. Coral reefs and rich marine life have made this stretch among the prime fishing and scuba diving destinations in the world. The area is also famous for its year-round sunny beaches and the spectacular coastal scenic drive where Galala Mountain reaches the Red Sea. Recently, development has started on the mountains following the construction of Galala Mountain Road. Galala City started with Galala University and several residential, touristic, and commercial facilities. This paper studies the pattern of development in the area during the past 40 years and assesses its impact on natural and cultural resources.

JOURNAL OF CONTEMPORARY URBAN AFFAIRS (2022), 6(1), 13-22. https://doi.org/10.25034/ijcua.2022.v6n1-2

www.ijcua.com

Copyright @ 2021 by Professor Dr. Yasser Mahgoub.

\section{Introduction}

Tourism has both positive and negative impacts on the environment and people. Tourism helps to create employment opportunities for a large number of people and increases the economic and sociocultural standards of the community while minimizing the migration to urban areas. It also promotes the conservation of natural features and the commercialization of local products and handicrafts. On the other hand, negative impacts include the increase of land use for construction, water for irrigation, and energy for services; the devastation of natural landscapes with the construction of more infrastructures; the increase in garbage and waste output and need for disposal; changes in ecosystems, including the introduction of non-indigenous animals and plants, and the

*Corresponding Author:

Faculty of Architecture, Galala University, Egypt

Email address: ymahgoub@gu.edu.eg 
disappearance of habitats; the increase of some illegal activities; the rise in the cost of products and services. Human activities affect the environment physically; individually or collectively, which may impact the long-term viability of tourism and related activities in the region. The environment must be preserved by all relevant parties in the tourist sector. Shaalan (2005) suggests that ambitious plans should consider sustainability as a guiding concept for development. Governments and developers have a critical role in establishing and enforcing rules and practices that safeguard natural heritage and the environment for future generations to enjoy (Shaalan, 2005).

The Ain-Sukhna-Zaafarana strip on the Red Sea Gulf of Suez, east of Cairo, has witnessed rapid development during the past 40 years due to its nature as an attractive mass tourism destination for Egyptians and foreigners. The type, intensity, and characteristics of this development and its impact on natural, built, and human environments are problematic. This rapid development is not sustainable and poses threats to the natural environment and human well-being, health, and safety. Several developments are located on natural rain flood paths, while others are extensively altering the natural environment to accommodate their units, as illustrated in Figure 1. Their economic feasibility is also questionable, as most of the units are used only a few days a year. The absence of planned public beaches and facilities is causing pollution due to the informal usage of the natural beaches. Informal developments are scattered along the coastal road in the form of seafood stands and restaurants.

This rapid development is causing negative impacts on the fragile natural environment and the human environment. For example, in 2016, a flash flood in Ras Gharib manifested the impact on unprotected areas, alerting the national government and the Red Sea local authorities of the hazards of rapid development. The threats and hazards include the pollution of the flora and fauna of the region; degradation of the quality of water, air, and visual characteristics; and natural disasters such as flash floods that can eradicate beaches and cause human fatalities, asset destruction, and investment losses. Negm and El-Sayed (2020) performed a study that concluded that climate change affects rainfall patterns and that Egypt started to experience different rainfall patterns during the early $21^{\text {st }}$ century (Negm \& El-Sayed, 2020). Mass tourism, informal use of beaches, and garbage are causing pollution and coral reef deaths. Natural beaches are no longer available with the rapid appropriation of beaches by gated resorts. The social and cultural heritage has disappeared entirely with the absence of local Bedouin tribes. Recently, development has started on the mountains following the construction of Galala Mountain Road. Galala City started with Galala University and several residential, touristic, and commercial facilities.

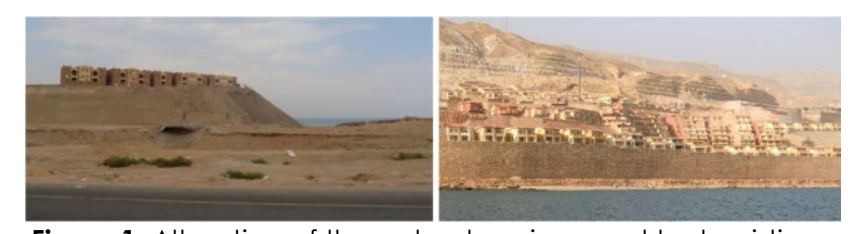

Figure 1. Alteration of the natural environment by touristic resorts. (Source: Author)

This paper investigates the developments during the past 40 years of the 60-kilometer coastal stretch between Ain-Sukhna (also known as Sukhna) and Zaafarana in the region of Galala Mountain, and their impact on the surrounding natural and cultural attractions. The questions posed are: What is the quality of current tourism development? How sustainable is it? How can we make it more sustainable? The results of this research could be useful for future planning in similar areas. They can increase the awareness of decision-makers about the adverse impact of unplanned development programs. The results should also be useful in improving the sustainability aspects of current facilities in the Ain-Sukhna region.

The paper adopts sustainability as a theoretical framework for the assessment of current development in the region. It asserts that sustainability is a process, not a product, a function not a form. The World Conservation Union (WCU) defines sustainable development as a development process that allows developments to take place without degrading or depleting the resources that make the development feasible. It goes on to define sustainable development as a change process in which resource exploitation, investment direction, technical development orientation, and institutional change are made consistent with future as well as current needs (Keeble, 1987).

Sustainable development entails not only environmental sustainability but also economic 
and social sustainability. As well as considering environmental impacts, urban designers need to have regard to social impacts and long-term economic viability. The notion of sustainability is now widely recognized as a critical component of any sort of development evaluation, including tourism. The World Tourism Organization (WTO), the Tourism Council (WTTC), and the Earth Council describe sustainable tourism as satisfying the demands of current visitors and host regions while safeguarding and expanding future opportunities. The concept of sustainable tourism arose with the goal of reducing the negative consequences of tourism operations, and it has since gained widespread acceptance as a desirable and politically suitable approach to tourist development.

Sustainable Tourism Development (STD) concerns economic, social, and environmental tourism development that aims at the continuous improvement of tourists' experience. As indicated by Franzoni (2015), "to measure tourism sustainability requires a knowledge of the complexity of tourism systems and the specifics of any given location. However, most research, although focusing on social, economic or environmental indicators but have not considered how they integrate and relate to each other" (Franzoni, 2015). Adillon (2018) presented a model of sustainable tourism that assists organizations in making informed decisions to control the number of visitors to destinations and attractions to achieve optimum utilization without compromising the future of these destinations (Adillon, 2018).

Red Sea tourism development has received several warning signs from researchers since the 1990s. Hawkins and Roberts (1996) indicated while present levels of recreational usage give the impression of being sustainable, the immense growth anticipated throughout the area will cast doubt on the region's longterm future sustainability. They cautioned that unless the rate of tourism expansion in the northern Red Sea was slowed, there would be extensive coral reef deterioration (Hawkins \& Roberts, 1996). Their prediction proved correct with vast areas of reef degradation observed in the northern parts of the Red Sea, especially in the Gulf of Suez and the entrance of the Suez Canal.

Several researchers indicated that rapid development in the region has resulted in pollution and environmental degradation. According to Abdallah (2007), the Ain-Sukhna area lies on the northwestern part of the Gulf of Suez and is characterized by the presence of highly sensitive and fragile natural resources, habitats, a wide coastal plain, an extensive tidal flat, and an important coral reef. The rise of tourism activities, the development of AinSukhna port and resorts, and the ensuing increase in population have all contributed to rapid and rising changes in land-use patterns in this area in recent decades. The area is now suffering from environmental contamination and the loss of various natural resources as a result. Abdallah's research aimed to highlight environmental changes from 1984 to 2002 and investigated their effects on the ecology and environment of the Gulf of Suez's coastal zone. $\mathrm{He}$ also found that human activities and development initiatives were primarily responsible for significant land-use changes in the area, such as the building of resorts, highways, ports, industrials, and urban sites. He concluded that the newer scope attracts attention towards the arising hazards concerning bio-system, stability of urban and resort buildings, as well as pollution of petrochemical factories (Abdallah, 2007).

Gohar and Kondolf (2020) conducted a systematic comparison between ecotourism and conventional tourism, based on a group of 37 resorts along Egypt's southern Red Sea coast. All resorts were built on similarly oriented plots between the sea and the Red Sea Mountain Range. They evaluated the resorts based on environmental criteria that included swimming pool surface area, distance from mangrove areas, the proximity of flood plains, the amount of grass space, and methods of access to deep water. They concluded that self-identified ecotourism facilities were not considerably different from the regular ones (Gohar \& Kondolf, 2020).

Bratucu et al. (2017) conducted a study on sustainable tourist development strategies in Romania's Carpathian Mountains, in which they confirmed that despite the fact that overdevelopment of mountain tourism may lead to environmental degradation and biodiversity loss, mountains and their landscapes are important resources for the tourism sector (Bratucu, et al., 2017). This is confirmed by Malik and Bhat's study (2015) in the Himalayan area, where tourism has both environmental and socioeconomic repercussions, with mountain 
tourism in particular being of concern because it is commonly utilized to promote community development while also destroying the environment (Malik \& Bhat, 2015).

\section{Sukhna Development}

This paper studies the chronological development of the region to understand the conditions in the area and the major changes in the natural environment. As suggested by the research of Abdul Rahman et al. (2020), visual surveys were used to observe the interaction between the natural and urban environment, (Abdul Rahman, Ghani, Teh, \& Ibrahim, 2020). Through physical and activity mapping, they made field observations to obtain information on the functional characteristics of the real scenes of the place. They discovered that the interaction between the physical environment and the users' actions greatly affected the quality of place and fabric (Abdul Rahman, Ghani, Teh, \& Ibrahim, 2020). This paper analyses several examples of major developments in the region and compares their planning, massing, and pattern of development. Satellite photos obtained from Google Earth were used for this analysis.

Sukhna is an important touristic attraction, mainly for Egyptian citizens. Situated approximately 55 kilometers south of Suez City and 120 kilometers east of Cairo, it is a popular tourism destination due to its proximity to the capital Cairo, year-round sunshine, clear water, beautiful sandy beaches, gentle waves, magnificent mountain scenes, and a spectacular scenic drive where the mountains reach the coastal road. Before recent development, it was known as the ideal location for camping and one-day school trips. It enjoys excellent weather all year round. According to weather reports, the average minimum temperature in winter is $7^{\circ}$ while the average maximum temperature in summer is $34^{\circ}$. The average annual rainfall is $17 \mathrm{~mm}$. Wind directions are NW, $N$, and $W$, with general speeds ranging between 11 and $20 \mathrm{~km} /$ hour. The area is famous for coral reefs, rich marine life, and fishing sites that have made this area one of the best scuba diving locations in the world.

Only 60 kilometers south of Sukhna lies Zaafarana, one of the world's premier diving locations that are famous for underwater photography as well as windsurfing and kitesurfing. Desert safaris into the mountains, canyons, and oases are other adventurous attractions. The area is also close to the Suez Canal and several Christian monasteries, including St. Anthony's Monastery and the Monastery of St. Paul, one of the oldest inhabited monasteries in Egypt. The opening of Galala Mountain Road has made access to the area easier and enjoyable. It reaches an elevation of 1,100 meters above sea level. It hosts many native species of animals and plants.
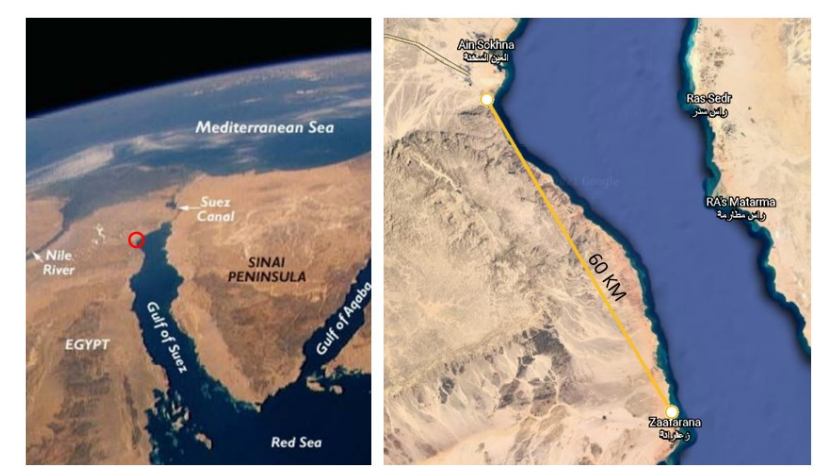

Figure 2. Map of Sinai, Gulf of Suez, and Sukhna-Zaafarana stretch.

As previously stated, Sukhna is the short name of Ain-Sukhna, which means "Hot Spring" in Arabic. It is the location of a hot sulfuric mineral spring that flows from Gebel Ataqa, the Eastern Desert's northernmost mountain, a few kilometers south of the port, which was known for its healing effects on dermatological and rheumatic diseases. Just behind the hot spring lies an archaeological site of an ancient Egyptian port that was used to import copper and sapphire from Sinai and trade with Pont in Africa. Recent archaeological discoveries indicated that the area hosted ports since the time of King Khufu. Hieroglyphic inscriptions were first discovered here in 1999 by Mahmud Abd El Raziq. Since then, archaeological investigations have been carried out here regularly. Some researchers claim that the crossing of the Red Sea at the exodus from Egypt took place at the northern end of the Gulf of Suez, and identify Ayun Moussa across from Ain-Sukhna as the place of crossing. During the Roman and Arab times, the Red Sea was known as al-Qalzam Sea, after a small village called Clysma or Klysma, that existed around the third century BC and was located near today's Suez City. It was a Roman trading port between the Red Sea and the Mediterranean Sea. The area became the 
Muslim Qulzum in the 7th century. The Ottomans developed the city, known as Suez, as a major port for trade with Arabia, Yemen, and India. The port later declined until the opening of the Suez Canal in 1869.

The area became popular again during the 1940 s as a vacation location accessible by automobiles. Before the 1967 war, the area was known as a fishing, diving, and camping ground. It was also known for its mineral sulfuric springs. It was usually featured in films (such as Ibn Hamedo 1957) as virgin and scenic, with sandy and sunny beaches all year long. It was a usual winter day trip for many school children. Between 1967 and 1977, the area was declared a military restricted zone and was closed for civilian activities. It was part of the battlegrounds of the War of Attrition, especially between 1967 and 1970.
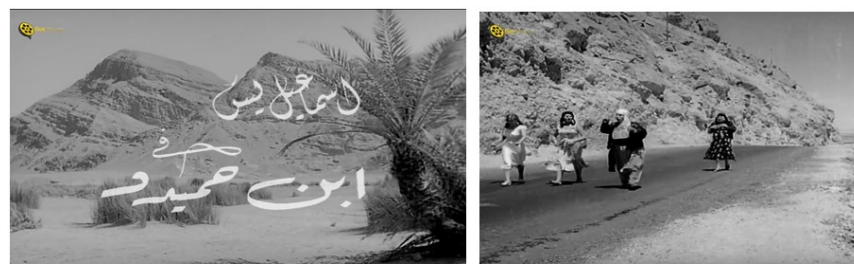

Figure 3. Sukhna as depicted in the 1957 film Ibn Hamedo.

After the 1973 war, the reopening of the Suez Canal in 1975, and the signing of the peace treaty in 1977, restricted access to the area was lifted, and fishing, diving, and camping activities resumed. Since the late 1970s, the area has witnessed rapid construction of touristic facilities and resorts that produced a negative impact on the fragile natural and cultural heritage. Between 1977 and 1997, early development and projects started with traditional seafood restaurants, small hotels, and touristic villages. The development started at the northern end and extended southward. The first hotel and resorts to appear were Sukhna Hotel, al-Higaz resort and Portrait hotel.
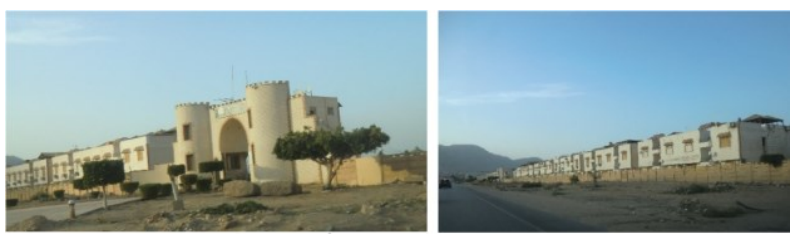

Figure 4. Early touristic resorts and hotels. (Source: Author)
In 2007 Porto Sukhna was launched as a giant development spreading over 2.5 million square meters extending into the mountain up to 270 meters above sea level. Until recently, it was considered the most ambitious residential development to be constructed on the mountain compared to the adjacent La Siesta resort composed of few villas on the mountain. In addition, it offered the first mountaintop golf course overlooking the Red Sea and a mountaintop seafood restaurant and shopping mall. Porto Sukhna was the first major touristic development in Egypt to be built on the mountain, not the beach, that contained international chain restaurants, cafes, shops, games, and other entertainment amenities. A cable car connected the mountain to the beach for the first time in Egypt. The iconic curved wavey-shaped towers - known as the pyramids - caught the attention of travellers and tourists and increased surrounding land value and attraction to the region. The "Portostyle" changed the traditional idea about coastal development and entertainment in Egypt. This type of development was duplicated in many parts of Egypt from the Red Sea to the Northwest Coast and other parts of the country. The Post-Porto style was characterized by extensive development, leisure attractions, colourful facades, expensive materials, exotic shapes, and international styles encouraged by luxurious gated resorts, such as La Vista and Telal.

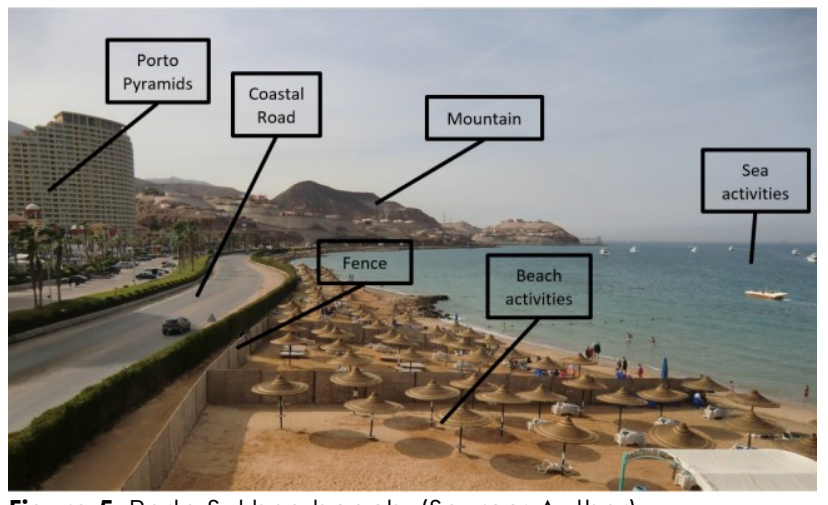

Figure 5. Porto Sukhna beach. (Source: Author) 

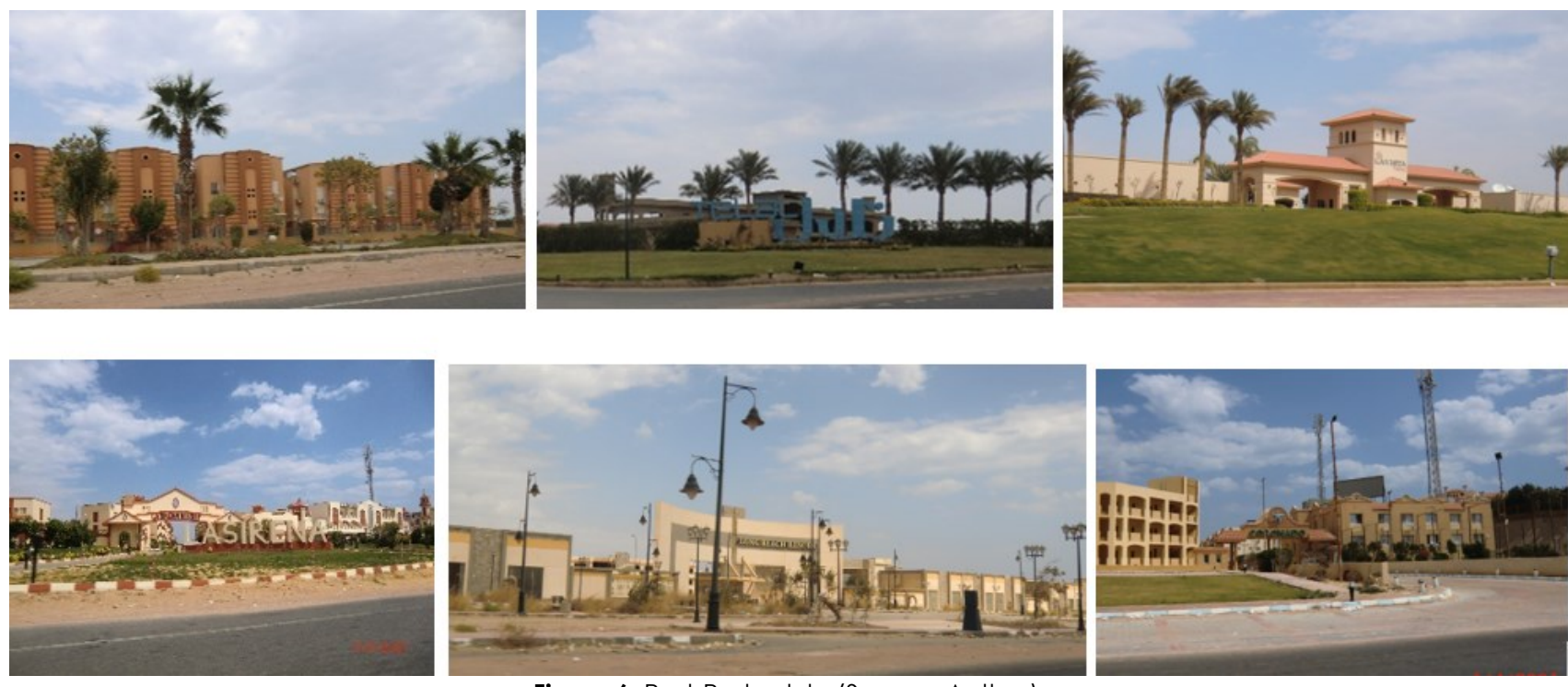

Figure 6. Post-Porto style (Source: Author)

Recently, development has started on the Galala Mountain Plateau following the construction of Galala Mountain Road. Galala. Galala City contains several developments at different levels from sea level to more than 700 meters above sea level. The Galala Mountain Panoramic Corniche is breathtaking. Galala City is located 700 meters above sea level on the Galala al-Bahariya Mountains between Ain-Sukhna and Zaafarana, covering approximately 19,000 feddans. Galala City is one of several new cities that the government aims to develop in the large Eastern and Western Deserts of Egypt. These new cities aim to attract the population from Cairo and other crowded urban centres by providing investment chances, work opportunities, and better living conditions, especially for the young generation. More than 100 local civil companies have participated in the construction process under the supervision of the Armed Forces Engineering Authority. The project started in January 2014 and provided more than 150,000 job opportunities. The project started with an 82-kilometer mountainous road connecting the CairoSukhna Road and the Zaafarana-Beni Suef Road, integrating the city with major centres in the country. The project creates a new urban community centred around Galala University with housing, services, and employment opportunities for thousands of people. The project accommodates a tourist resort, hotel, and restaurants on the mountaintop enjoying the magnificent scenery. A cable car connects the mountain city with a 1,000-feddan seafront resort containing a hotel, aqua park, yacht marina, and shopping centres. The project is served by water from a desalination plant providing 150,000 cubic meters a day of potable water, and by electricity from a power plant and wind farms. The goal is to create an urban community where Egyptians can enjoy a decent quality of life all year round in this magnificent location.

The Galala City master plan aims to create sustainable, active, mixed-use public transit, new road systems, and public spaces that take into account the existing ecological conditions. The first of the three phases of the city comprise a total of 2,050 acres and includes a variety of activities. Residential districts with the most desirable reasonably priced units, touristic villages, and commercial, cultural, medical, educational, and religious institutions are all included. These institutions are linked to the project's public arena, which houses the convention centre as well as the city's largest mosque. The consultant SITES International office was in charge of the infrastructure that comprised irrigation, sewage treatment plants, massive water tanks, and preparations for solar-powered illumination in public spaces. The city's masterpiece is the breath-taking 6-kilometer mountain plateau corniche walkway, with a drop of 200 meters. In addition to affording fascinating perspectives of the neighbouring residential and tourist settlements, the promenade features vantage points of the Gulf of Suez and neighbouring plateaus, a cycling track, a mix of cafes, restaurants, pedestrian routes, and covered lounging places. As previously mentioned, the mountain city is connected with the seaside Galala Resort by a cable car. 
Building materials are acquired from quarries in the Red Sea region, and the landscaping is environmentally friendly. The surrounding ecosystem is protected with minimal changes due to the use of indigenous and semiindigenous plants, trees, and ground cover palettes, as well as recycled water and an effective water conservation irrigation system.

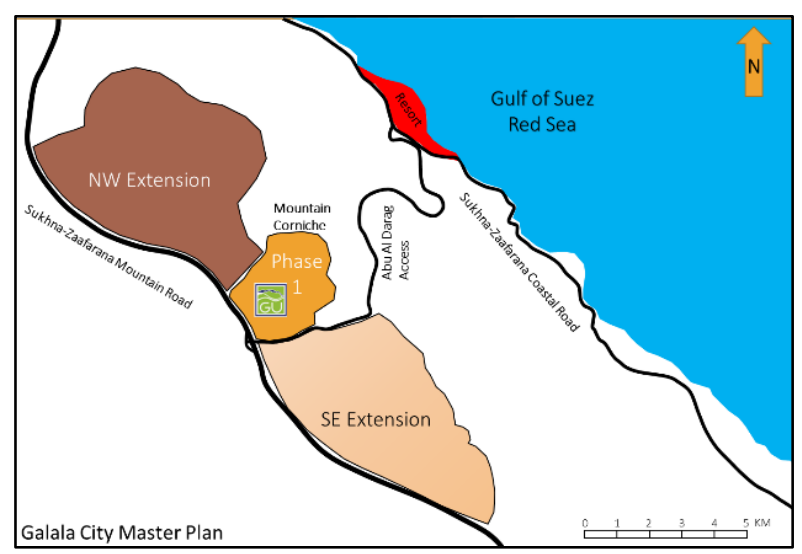

Figure 7. Galala City Master Plan. (Source: Author)

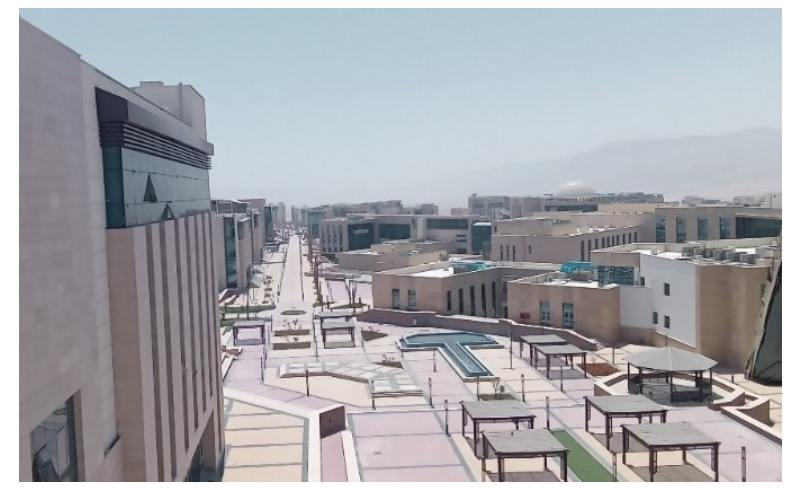

Figure 8. Galala University campus. (Source: Author)

\section{Results}

This paper investigated the impact of rapid development on the environment in the Sukhna region. It questioned whether this development was sustainable or not. It applied the three aspects of sustainability to analyze the region, namely environment, economy, and equity.

Environmentally, the rapid development affected land, sea, and air quality. The natural environment has been radically modified. The mountains are being terraced for development. The debris of these excavations is thrown to the sides of the mountains and will create hazards during heavy rains due to unpredictable changes in rain flood paths. Seawater is polluted by garbage discarded by big and small boats. This and other beach activities damage the coral and other marine life. Heavy truck traffic is damaging the zigzag coastal roads. Many accidents occur due to reckless driving and narrow road. It is very difficult to widen the road due to the adjacent mountain ridge and the coast.

The built environment touristic resorts are occupying hazardous locations in floodplains along the coast. Many structures are located in the path of flash floods. The architecture of all the buildings does not consider the natural environment in terms of building orientation, openings, materials, or passive cooling systems. Almost all units depend on air conditioners. The landscape design of the residential gated communities applies an English-style landscape of large green lawns and plants that require large amounts of water from irrigation. Whether this water is recycled or not, huge amounts of freshwater are being injected into the ground with unforeseen consequences. The area suffers from irregular construction activities, abandoned buildings and structures of the early development, and informal fish sales kiosks and restaurants scattered along the coastal road.

Economically, investments in Sukhna are affected by environmental hazards. The high levels of investment have a low rate of return and utilization. The high cost of maintenance of luxurious resorts will increase over time. Villas and chalets are used as a weekend house for only a few days every year. The type of architecture and investment is not supported by permanent work opportunities. Recently the establishment of Sukhna Port, Galala University, and heavy industries has encouraged people to live in the area for extended periods. Yet the running cost of this type of housing and touristic facilities is high, due to water shortage and a large number of swimming pools and gardens, and high energy consumption for continuous air-conditioning due to the lack of passive cooling and sun protection. The landscape is consuming too much water and requires continuous maintenance.

The economy of the region depends on the availability of assistance workers to provide services in shops, housekeeping, restaurants, etc. There is no consideration of the needs of these low-income groups. There are no bus terminals or transportation hubs to serve their needs. There are no proper accommodation alternatives for them. There are no public beaches for ordinary people to enjoy. Most beaches are appropriated by gated 
communities. In the past, people used to visit this place for day use. Now there is no place for low-income people or non-owners to enjoy the region. No proper housing or accommodation is provided for the limited-income strata of the population.

\section{Discussions}

This paper proposes a Sustainable Tourism Development Model to study the current problems in the region and propose solutions and approaches to any new development. The model is defined as development that improves the environment, economy, and quality of life of the inhabitants of the region while providing a significant experience for tourists and visitors. The framework covers four dimensions: natural, built, human, and economic.

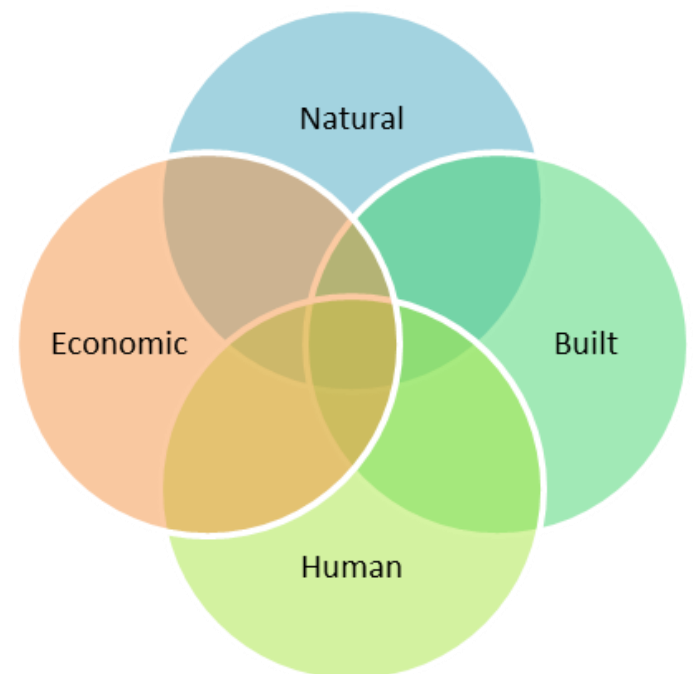

Figure 9. The Sustainable Tourism Development Model.

a). Natural Environment Sustainability

- Protect nature and the coastal area for future generations. Declare parts of the coast as UNESCO Heritage sites.

- Trucks are crowding the coastal road and causing traffic hazards, air pollution, and noise. They should be prohibited from this coastal road during daytime and allowed only during specific nighttime.

- Restore and renovate the original site of the hot spring (Ain-Sukhna). Currently, the Sukhna water spring is surrounded by a fence and is not accessible. The hot spring has great potential to initiate health tourism activities. A health resort and a wellness centre can be established there.

- Study environmental hazards of flash flooding and landslides.

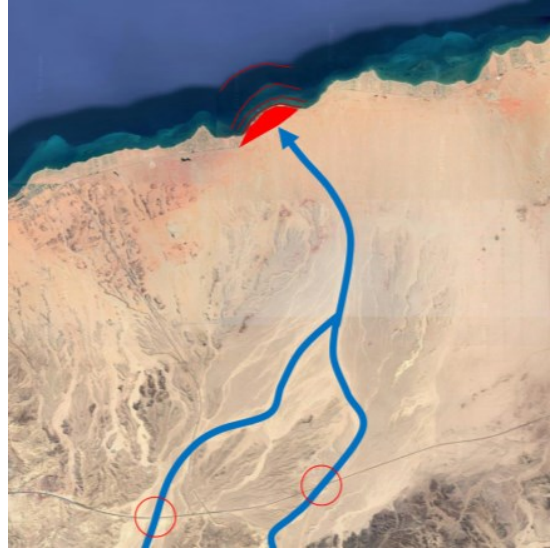

Figure 10. Example of the potential hazard of flash floods.

b). Built Environment Sustainability

- Enforce existing building laws of setback from sea line and buildings.

- Establish guidelines for planning and architectural design to achieve sustainability. Current buildings do not consider the environment; they are mainly commercial consumption and stylistic statements.

- Provide beaches and fishing piers for public use. Resorts constructed on the mountain are claiming the beaches by building fences around them for their exclusive use.

- Apply sustainability and ecotourism strategies to all facilities and attractions.

- Develop building guidelines to use materials, colors, and shapes to give the area a distinctive identity and style.

- Develop sustainable guidelines, to be implemented by current and future developments, that include urban and architecture guidelines, water and electricity conservation, materials and methods of construction, design guidelines, passive energy conservation, application of sustainability assessment, application of Environmental Impact Assessment certification that is renewable every five years.

- Design buildings to withstand the impacts of climate change. Increased number or intensity of weather events increases the requirement for resilient buildings. 


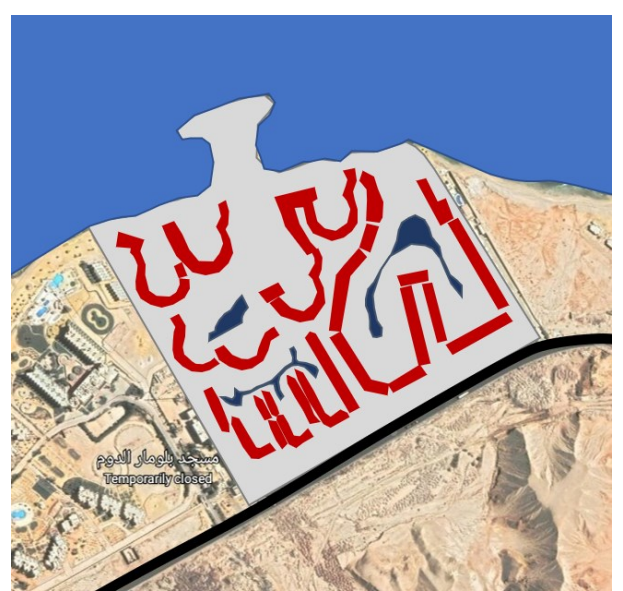

Figure 11. Resort buildings footprint examples.

\section{c). Human-Environment Sustainability}

- Provide accessibility for different economic and social groups to public beaches and facilities. People who do not have permanent accommodation or who cannot afford to rent should be provided with open beaches and facilities such as changing rooms, toilets, and showers. Those who are interested in fishing should be provided with fishing piers with affordable entry fees. Providing public access to public beaches will achieve equity between all citizens of Egypt from different economic levels.

- High-income tourists' facilities require a workforce (servants, drivers, housekeepers, gardeners, salespersons, etc.) who require means of transportation. Many workers stay temporarily in Sukhna during the weekdays and go to their hometowns during the weekends or monthly vacations. There is no proper transportation hub to serve their needs. The informal bus stops in front of McDonald's are causing traffic jams and safety hazards for pedestrians.

- The location of the informal bus parking area is very dangerous for the users. They have to cross the busy coastal road back and forth. Bridges or speed humps should be provided.

d). Economic Sustainability

- Consider alternative means of investment to replace the very low rates of use. Many owners do not use these assets efficiently, coming only a few days a month or year because of their time restrictions and places of residence. Providing more work opportunities like Galala University, industrial, trading, and oil facilities will increase the use of these assets through renting or use by students and university employees.

\section{Conclusions}

The study of the development of the SukhnaZaafarana stretch reveals several challenges related to the preservation of the nature of the coastal road. The first challenge is to conserve the unique and sensitive natural and cultural resources, notably the coastal zone. The coastal road is being dramatically modified to provide more areas for development along the beach, especially for gated communities and resorts. The nature of the mountains and the coastal road is being eroded rapidly and replaced by planned and constructed roads. Permanent construction of high walls and land infill of sea beaches is destroying marine life and causing coral reef degradation. The area suffers from heavy truck traffic along the coastal road, causing air, land, visual, and noise pollution and deteriorating the original site attractions. We need to fully understand that this type of development near a fragile environment has dangers and hazards, which have been experienced by other countries before. The area is mainly used by local tourists, not international tourists. This is similar to the development in the Northwest Coast of Egypt. The study revealed that the characteristics of the destination's carrying capacity and the resident community quality of life should be kept in mind, along with the visitors' experiences. Similar to the Sinai Peninsula, the Sukhna-Zaafarana stretch suffers from unexpected heavy rainfall and severe weather conditions as major causes of many flash floods (ElAfandi \& Morsy, 2020). There should be continuous monitoring of the environmental and urban changes in the region and their mutual impact. An Environment and Development Observatory is being established at Galala University, utilizing its specializations and facilities, especially the Geoinformatics laboratory, to continuously monitor these changes and issue a regular newsletter of the region's status and potential hazards. This area is of paramount importance for the Egyptian economy due to its proximity to Cairo and the New Administrative Capital. Its protection through continuous assessment of environmental changes and hazards would prevent significant loss of lives and assets. In order to prevent or reduce flash flood 
tragedies, accurate rainfall forecasting is essential.

\section{Acknowledgement}

This research did not receive any specific grant from funding agencies in the public, commercial, or not-for-profit sectors.

\section{Conflict of interests}

The author declares no conflict of interest.

\section{References}

Abdallah, A. (2007). Monitoring Environmental Changes in El-Ain El-Sokhna Area, Gulf of Suez, Egypt. Nine Conference for Geographical and GIS Department. 1. Alexandria: Faculty of Arts, Alexandria University. https://doi.org/10.13140/RG.2.1.4125.1365

Abdul Rahman, N., Ghani, I., Teh, M., \& Ibrahim, K. (2020). Rethinking Urban Public Space: Physical and Functional Analysis through Visual Surveys. The 1st International Conference on Urban Design and Planning. 409. IOP Conf. Series: Earth and Environmental Science. https://doi.org/10.1088/1755-1315/409/1/012002

Adillon, R. (2018). Diamond Model: A theoretical framework for the sustainable development of tourism. Arts \& Humanities Open Access Journal, $3(1)$, $11-23$. https://doi.org/10.15406/ahoaj.2019.03.00099

Bauer, A. H., Tügel, F., \& Hinkelmann, R. (2020). Flash Flood Investigations in El Gouna, Northern Red Sea Governorate. In Egypt. In A. M. (ed.), Flash Floods in Egypt: Advances in Science, Technology \& Innovation. Springer Nature. https://doi.org/10.1007/978-3-030-29635-3_5

Bratucu, G., Baltescu, C., Neacsu, N., Boscor, D., Tierean, O., \& Madar, A. (2017). Approaching the Sustainable Development Practices in Mountain Tourism in the Romanian Carpathians. Sustainability, $9(11)$.
ElAfandi, G., \& Morsy, M. (2020). Developing an Early Warning System for Flash Flood in Egypt: Case Study Sinai Peninsula. In A. Negm, Flash Floods In Egypt: Advances in Science, Technology \& Innovation (pp. 45-60). (IEREK Interdisciplinary Series for Sustainable Development), Springer Nature. https://doi.org/10.1007/978-3-030-2963534

Franzoni, S. (2015). Measuring the sustainability performance of the tourism sector. Tourism Management Perspectives, 16, 22-27. https://doi.org/10.1016/j.tmp.2015.05.007

Gohar, A., \& Kondolf, M. G. (2020). How Eco is EcoTourism? A Systematic Assessment of Resorts on the Red Sea, Egypt. Sustainability, 12(23). https://doi.org/10.3390/su122310139

Hawkins, J., \& Roberts, C. (1996). The growth of coastal tourism in the Red Sea: present and possible future effects on coral reefs : J. P. Hawkins \& C. M. Roberts, in: Proceedings of the colloquium on global aspects of coral reefs, Miami, 1993, ed R.N. Ginsburg \& F.G.W. Smith. Biological Conservation, $\quad 76(2), \quad 216$ https://doi.org/10.1016/0006-3207(96)83261-7

Keeble, B. (1987). The Brundtland commission: Environment and development to the year 2000. Medicine and War, 3(4), 207-210. https://doi.org/10.1080/07488008708408769

Malik, M., \& Bhat, M. (2015). Sustainability of tourism development in Kashmir-Is paradise lost? Tourism Management Perspectives, 16, 11-21. https://doi.org/10.1016/j.tmp.2015.05.006

Negm, A., \& El-Sayed, O. (2020). Introduction to "Flash Floods in Egypt". In A. Negm, \& A. M. Negm (Ed.), Flash Floods in Egypt (pp. 3-9). IEREK Interdisciplinary Series for Sustainable Development, Springer. https://doi.org/10.1007/978-3-030-29635-3

Shaalan, I. M. (2005). Sustainable tourism development in the Red Sea of Egypt threats and opportunities. Journal of Cleaner Production, 13(2), 83-87. https://doi.org/10.1016/j.jclepro.2003.12.012 